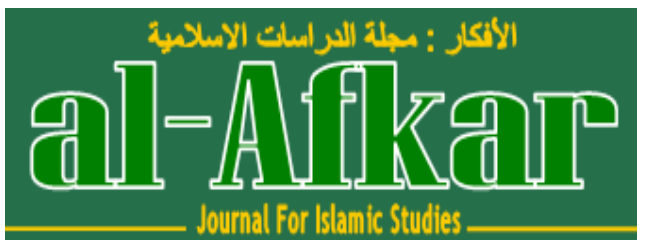

Vol. 2, No. 2, July 2019

P-ISSN : 2614-4883; E-ISSN : 2614-4905

https://al-afkar.com/index.php/Afkar_Journal/issue/view/4

DOI: https://doi.org/10.31943/afkar_journal.v4i1.62

\title{
PEMANFAATAN BARANG GADAI DITINJAU DARI HUKUM ISLAM DAN HUKUM PERDATA INDONESIA
}

\author{
Hani Sholihah \\ Sekolah Tinggi Agama Islam Nahdlatul Ulama (STAINU) Tasikmalaya \\ E-Mail: hanisholihahı23@gmail.com \\ Anna Ramadhiana \\ Sekolah Tinggi Agama Islam Nahdlatul Ulama (STAINU) Tasikmalaya \\ E-Mail: annaramadhianasukses@gmail.com
}

\begin{tabular}{|c|c|c|}
\hline Received & Revised & Accepted \\
\hline 3 Juny 2019 & 20 Juny 2019 & 1 July 2019 \\
\hline
\end{tabular}

\section{THE UTILIZATION OF PAWING GOODS VIEWED FROM ISLAMIC LAW AND CIVIL LAW IN INDONESIA}

\begin{abstract}
Various transactions conducted by humans to achieve the necessary. One type of economic transaction (mu'amalah) is wont to do is pledge, namely submission of an object (goods), as a guarantee to the person who gives the loan. This study aims to determine: a) the provisions of lien according to Islamic law; b) pledge by the Civil Code provisions; and c) the use of goods lien law based on Islamic law and the Civil Code. The study concluded: 1) according to Islamic law, a pledge was made items that have a property value in the eyes of Personality 'as collateral, so that the person concerned may take debt or he can take some of the benefits that their goods; 2) according to civil law, lien is a creditor or the rights acquired by proxies as collateral for debts, and authorizes the creditor to take payment of accounts receivable; 3 ) the scholars differed on the use of goods pawn. As for the positive law, goods pledge not to use it for safekeeping, so that perishable goods must not be mortgaged.
\end{abstract}

Keywords: pawn, Islamic law, civil law. 


\begin{abstract}
Abstrak
Berbagai transaksi dilakukan manusia untuk memenuhi kebutuhan hidupnya. Salah satu jenis transaksi ekonomi (mu'amalah) yang biasa dilakukan adalah gadai, yaitu penyerahan suatu benda (barang), sebagai jaminan kepada orang yang memberikan pinjaman. Penelitian ini bertujuan untuk mengetahui: a) ketentuan gadai menurut hukum Islam; b) ketentuan gadai menurut KUHPerdata; dan c) hukum pemanfaatan barang gadai berdasarkan hukum Islam dan KUHPerdata. Hasil penelitian menyimpulkan: 1) menurut hukum Islam, gadai adalah menjadikan barang yang mempunyai nilai harta menurut pandangan syara' sebagai jaminan utang, sehingga orang yang bersangkutan boleh mengambil utang atau ia dapat mengambil sebagian manfaat barangnya itu; 2) menurut hukum perdata, gadai adalah suatu hak yang diperoleh kreditur atau oleh kuasanya sebagai jaminan atas utangnya, dan memberi wewenang kepada kreditur untuk mengambil pelunasan piutangnya; 3) para ulama berbeda pendapat tentang pemanfaatan barang gadai. Adapun menurut hukum positif, barang gadai bukan untuk digunakan melainkan untuk disimpan, sehingga barang yang cepat rusak tidak boleh digadaikan.
\end{abstract}

Kata kunci: gadai, hukum Islam, hukum perdata.

\title{
Pendahuluan
}

Sebagai makhluk hidup yang dianggap paling sempurna karena memiliki akal, maka kehidupan manusia pun tidak pernah lepas dari aturan, sebagaimana istilah dalam ilmu hukum di mana ada masyarakat maka di sana ada hukum. Segala sesuatu yang menyangkut manusia baik dari segi ibadah maupun mu'amalah sudah diatur oleh Allah SWT. Dalam segi ibadah tentu sifatnya individual, namun dalam segi mu'amalah manusia tidak dapat melakukannya secara sendiri, melainkan perlu ada hubungan dengan orang lain. Bidang ini yang seringkali menjadi pemicu adanya konflik pada kehidupan manusia. Untuk itu, hukum Islam sangat memperhatikan urusan manusia dalam bidang mu'amalah dengan berbagai syarat dan ketentuan yang harus dipenuhi agar kegiatan mu'amalah tersebut berjalan dengan baik tanpa adanya saling merugikan antara yang satu dengan yang lain.

Di samping hukum Islam, sebagai warga negara Indonesia ada hukum yang harus ditaati secara resmi yang disebut hukum positif. Jadi warga negara Indonesia diatur dalam suatu hukum yang disebut hukum positif, yaitu hukum yang diberlakukan secara sah di suatu negara. Hukum positif di Indonesia bersumber dari hukum Islam, hukum barat dan hukum adat ${ }^{1}$.

Selain dari manusia terikat oleh aturan manusia juga sebagai makhluk hidup wajib mempertahankan hidup dengan cara memenuhi kebutuhan hidupnya. Salah satu cara pemenuhan kebutuhan hidup adalah dengan adanya kegiatan usaha dengan berbagai cara seperti mu'amalah. Salah satu jenis mu'amalah adalah gadai.

\footnotetext{
${ }^{1}$ Abd Muin and Ahmad Khotibul Umam, "EKSISTENSI KOMPILASI HUKUM ISLAM DALAM SISTEM HUKUM POSITIF," Risâlah, Jurnal Pendidikan Dan Studi Islam 3, no. 1 (2016): 63-77.
} 
Gadai merupakan salah satu praktek fiqh dalam bidang mu'amalah yang sering dilakukan oleh masyarakat dengan tujuan untuk memberi jaminan kepada orang yang meminjamkan uang, jika kelak si peminjam uang tidak dapat mengembalikan atau membayar hutangnya. Atau singkatnya gadai adalah menjadikan harta benda sebagai jaminan atas hutang ${ }^{2}$. Sama halnya dengan mu'amalah lainnya gadai juga memiliki syarat-syarat dan rukun tertentu yang harus dilakukan baik oleh penerima gadai ataupun oleh pemberi gadai (orang yang berhutang).

Dalam Kitab Undang-Undang Hukum Perdata atau Burgerlijk Wetboek pasal 1150 disebutkan bahwa "gadai adalah suatu hak yang diperoleh kreditur atas suatu barang bergerak yang diserahkan kepadanya oleh kreditur atau oleh kuasanya sebagai jaminan atas utangnya.... ${ }^{3}$.

Dalam hal tidak untuk dipakai terdapat penyimpangan dengan adat kebiasaan masyarakat yang terkadang barang gadai itu dipakai atau dimanfaatkan layaknya barang milik sendiri. Dalam kenyataan di masyarakat sering terjadi, misalnya seseorang menggadaikan sawah. Sawah tersebut kemudian digarap oleh penerima gadai, ditanami dan hasilnya dimanfaatkan pula oleh penerima gadai. Atau motor yang digadaikan juga dipakai layaknya motor milik sendiri.

\section{Landasan Teori}

\section{Ketentuan Gadai Menurut Hukum Islam.}

\section{Pengertian Gadai}

Gadai menurut bahasa adalah ats-tsubūt artinya tetap. Ada pula yang menyebutkan al-ihtibās artinya menahan. Pengertian ini diambil dari ayat Al-Quran Surat Al-Muddatsir ayat 38:

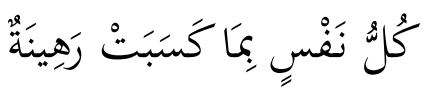

”...tiap-tiap jiwa tertahan (untuk mempertanggungjawabkan) atas apa yang telah diperbuatnya". (Al-Muddatsir [74]:38)

Sedangkan gadai menurut istilah adalah menjadikan harta sebagai jaminan atas utang. Berdasarkan Al-Quran Surat Al-Baqarah ayat 283:

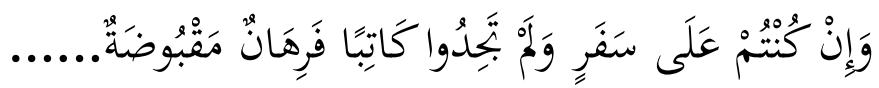

Artinya:

"dan jika kamu dalam perjalanan sedang kamu tidak mendapatkan seorang penulis, maka hendaklah ada barang jaminan yang dipegang.... (AlBaqarah[2]:283).

\footnotetext{
${ }^{2}$ Imam Taqiyuddin, "Kifayat Al-Akhyar Fi Hal Ghayat Al-Ikhtiyar" (Bandung: Al-Maarif, TT, n.d.).

${ }^{3}$ Sunarto Ady Wibowo, “Perwalian Menurut KUHP Perdata Dan UU No. 1 Tahun 1974," 2004.
} 
Selain Al-Quran, ada pula hadits Rasulullah SAW yang menerangkan tentang gadai, diantaranya hadits berikut:

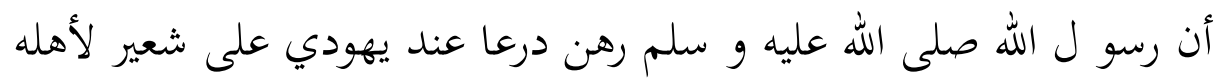

Artinya:

"Rasulullah SAW telah menggadaikan baju besi kepada seorang Yahudi atas sya'ir untuk keluarganya ${ }^{4}$.

Dalam kitab Al-Bajuri disebutkan bahwa gadai adalah menjadikan suatu benda berupa harta sebagai jaminan atas utang yang dapat memenuhi utang ketika peminjam tidak dapat melunasi utangnya ${ }^{5}$.

Sayyid Bakri Bin Sayyid Muhammad dalam kitabnya I'anat Ath-Thalibin menyatakan bahwa gadai adalah menjadikan harta benda yang boleh dijual sebagai jaminan atas utang yang akan memenuhi atau melunasi utang tersebut ketika peminjam tidak mampu untuk melunasi.

Sedangkan Wahbah Az-Zuhaili dalam kitabnya yaitu Al-Fiqh Al-Islam wa Adillatuhu menyatakan bahwa gadai adalah menjadikan benda yang memiliki harga dalam pandangan syara'untuk jadi jaminan atas utang, baik benda itu dimungkinkan dapat membayar keseluruhan utang atau sebagian dari utang ${ }^{6}$.

Definisi menurut empat madzhab yang dikutip oleh Wahbah Az-Zuhaili adalah sebagai berikut:

a. Syafi'iyah

Gadai adalah menjadikan harta sebagai kepercayan atas utang yang akan dilunasi oleh benda tersebut ketika utang tidak mampu dibayar.

b. Hanabilah

Gadai adalah harta benda yang dijadikan kepercayaan atas utang yang akan dibayarkan utang tersebut dari harga benda jika utang tidak dapat dilunasi.

c. Malikiyah

Gadai adalah sesuatu yang berharga yang diambil dari pemiliknya untuk jaminan sebuah utang yang tetap pada pemilik harta.

Menurut Sayid Sabiq yang dikutip oleh Suhrawardi dan Chairuman, gadai adalah menjadikan barang yang mempunyai nilai harta menurut pandangan syara' sebagai jaminan utang, hingga orang yang bersangkutan boleh mengambil utang atau ia bisa mengambil sebagian manfaat barangnya itu ${ }^{7}$.

\footnotetext{
${ }^{4}$ Taqiyuddin, "Kifayat Al-Akhyar Fi Hal Ghayat Al-Ikhtiyar."

${ }^{5}$ Syeikh Ibrahim Al Bajuri, “Hasyiah Al Bajuri „ala Ibnu Qosim Al Ghuzzi” (Jakarta: PT Karya Insani, n.d.).

${ }^{6}$ Wahbah Az-Zuhaili, “Al-Fiqh Al-Islam Wa Adillatuhu, Cet. Ke-3,” Damaskus: Dar Al-Fikr, 1989.

${ }^{7}$ Chairuman Pasaribu and Suhrawardi K Lubis, Hukum Perjanjian Dalam Islam (Penerbit Sinar Grafika, 1994).
} 
Berikut ilustrasi dari pengertian di atas: Si A meminjam utang kepada si B kemudian si A menyerahkan barang miliknya yang dapat dijadikan jaminan untuk melunasi utangnya jika nanti si A tidak dapat meunasi utangnya.

Imam Taqiyuddin berpendapat bahwa gadai adalah jaminan ketika seseorang berutang, yang dapat dijual untuk melunasi utang peminjam. Oleh karena itu, ketentuan tentang barang yang digadaikan adalah setiap benda yang dapat dijualbelikan maka benda itu dapat digadaikan pula ${ }^{8}$.

Dari beberapa definisi di atas, dapat disimpulkan bahwa gadai adalah jaminan yang diberikan kepada pemberi utang ketika seseorang berutang, yang dapat dijual untuk melunasi utangnya. Dengan demikian, barang yang digadaikan adalah setiap benda bernilai, yang dapat diperjualbelikan. Setiap benda yang dapat diperjualbelikan, maka benda itu dapat pula digadaikan.

\section{Hukum Gadai}

Gadai secara hukumnya diperbolehkan asalkan tidak mengandung unsur riba. Bahkan beberapa kali tercatat Rasulullah SAW.menggadaikan harta bendanya.

Rasulullah pernah ditanya tentang seseorang yang menggadaikan kambingnya, apakah kambing itu boleh diperah oleh orang yang dititipi kambing itu. Nabi mengizinkan, sekadar menutupi biaya pemeliharaan. Artinya Rasulullah SAW.mengizinkan mengambil keuntungan dari barang yang digadaikan untuk menutup biaya pemeliharaan ${ }^{9}$. Biaya pemeliharaan itulah yang kemudian dijadikan dasar ijtihad para oakar keuangan syari'ah, sehingga gadai atau rahn ini menjadi produk keuangan syarai'at yang menjanjikan.

Namun, pegadaian yang sering disaksikan sekarang, banyak yang melanggar aturan syari'at. Praktik ini dilakukan sekadar untuk pembungaan uang atau utang yang jelas-jelas diharamkan dalam semu agama samawi. Karena itu hukum gadai seperti ini haram.

\section{Dasar Hukum Gadai}

Ayat Al-Qur'an yang dapat dijadikan dasar hukum perjanjian gadai adalah QS. Al-Baqarah ayat 283, diantaranya adalah :

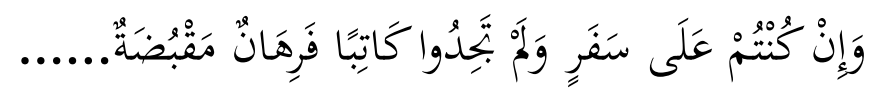

"jika kamu dalam perjalanan sedang kamu tidak memperoleh seorang penulis, maka hendaklah ada barang tanggungan yang dipegang (oleh yang berpiutang)".( Al-Baqarah[2] : 283).

\footnotetext{
${ }^{8}$ Taqiyuddin, "Kifayat Al-Akhyar Fi Hal Ghayat Al-Ikhtiyar."

${ }^{9}$ Sumadi Sumadi, "IDEOLOGI BIAS GENDER DALAM LEMBARAN FIKIH POPULER DI INDONESIA," Al-Afkar, Journal For Islamic Studies 1, no. 1 (2018): 1-15.
} 


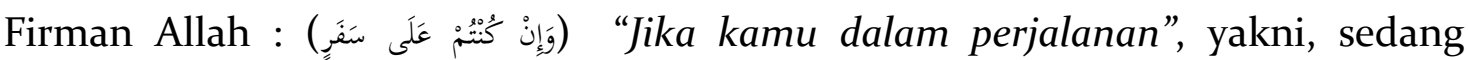
melakukan perjalanan dan terjadi hutang piutang sampai batas waktu tertentu, ( وَّمَ (بَحِدُوا كَاِتبًا menuliskan transaksi untukmu. Ibnu Abbas mengatakan: "Atau mereka mendapatkan seorang penulis, tetapi tidak mendapatkan kertas, tinta atau pena, maka hendaklah ada barang jaminan yang dipegang oleh pemberi pinjaman. Maksudnya, penulisan itu diganti dengan jaminan yang dipegang oleh si pemberi

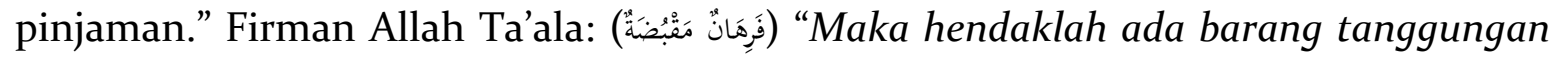
yang dipegang (oleh yang berpiutang)." Ayat ini dijadikan sebagai dalil yang menunjukkan bahwa jaminan harus merupakan sesuatu yang dapat dipegang. Sebagaimana yang menjadi pendapat Imam Syafi'i dan jumhur ulama. Dan ulama lain menjadikan ayat tersebut sebagai dalil bahwa barang jaminan itu harus berada ditangan orang yang memberikan gadai.

Menurut ayat yang tertera di atas, bahwasanya Al-Qur'an memperbolehkan adanya hukum akad gadai, dengan mengecualikan jika adanya unsur riba yang terdapat didalamnya. Sedangkan hadits yang menerangkan tentang gadai diantaranya adalah sebagai berikut:

a. Hadis riwayat Aisyah ra., ia berkata:

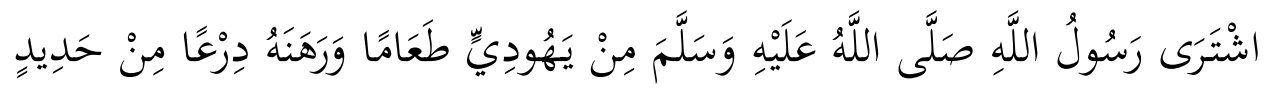

"Rasulullah saw. pernah membeli makanan dari seorang Yahudi dengan cara menangguhkan pembayarannya, lalu beliau menyerahkan baju besi beliau sebagai jaminan”. (Shahih Muslim)

b. Dari Abu Hurairah ra. Nabi SAW bersabda :

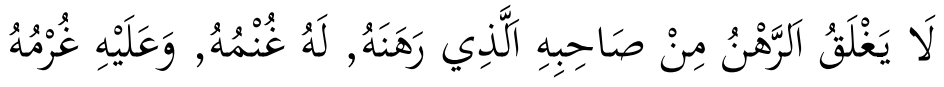

"Tidak terlepas kepemilikan barang gadai dari pemilik yang menggadaikannya. Ia memperoleh manfaat dan menanggung resikonya." (HR. Al-Hakim, alDaraquthni dan Ibnu Majah).

c. Nabi bersabda :

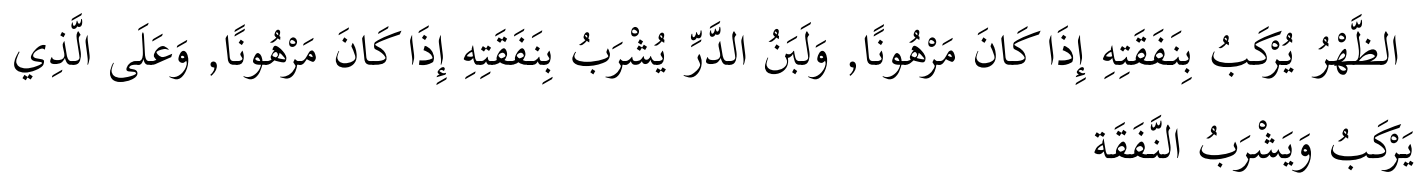

"Tunggangan (kendaraan) yang digadaikan boleh dinaiki dengan menanggung biayanya dan binatang ternak yang digadaikan dapat diperah susunya dengan menanggung biayanya. Bagi yang menggunakan kendaraan dan memerah susu wajib menyediakan biaya perawatan dan pemeliharaan”. (Shahih Muslim) 
d. Hadits:

$$
\text { ورن عائشة - رضي الله عنها- قالت يا رسول الله ! ان فلانا قدم له بز من الشام فلو بعثت }
$$

Dari Aisyah, ia berkata: Aku berkata: "Wahai Rasulullah, sesungguhnya barangbarang pakaian telah datang pada si Pulan dari Syam. Seandainya baginda mengutus seseorang kepadanya, maka baginda akan mendapatkan dua potong pakaian dengan pembayaran tunda hingga mampu membayarnya." Lalu Rasulullah mengutus seseorang kepadanya, namun pemiliknya menolak. (dikeluarkan oleh Al-Hakim dan Baihaqi dengan perawi-perawi yang dapat dipercaya ${ }^{10}$.

Ayat Al-Qur'an dan beberapa riwayat hadits di atas dijadikan dasar atas bolehnya transaksi gadai. Meskipun ayat Al-Qur'an memang tidak menyebutkan istilah gadai secara jelas, tetapi berbagai riwayat hadits di atas secara jelas menyatakan gadai. Dalam hal ini Hadits berfungsi sebagai penjelas Al-Qur'an.

\section{Rukun Gadai}

Ahmad Sarwat dalam bukunya yang berjudul Fiqh Sehari-hari menyimpulkan bahwa rukun gadai adalah sebagai berikut:

a. Ada lafadz, yaitu pernyataan perjanjian gadai. Lafadz dapat dilakukan secara tertulis ataupun lisan, yang penting di dalamnya terkandung maksud melakukan perjanjian gadai antara pihak yang bersangkutan.

b. Ada pemberi dan penerima gadai; keduanya haruslah orang yang berakal dan baligh sehingga cakap melakukan suatu perbuatan hukum sesuai ketentuan syari'at Islam.

c. Ada barang yang digadaikan. Barang yang digadaikan harus ada pada saat perjanjian gadai dilakukan dan barang itu adalah milik si pemberi gadai. Barang gadaian kemudian berada di bawah pengawasan penerima gadai.

d. Ada utang yang bersifat tetap, tidak berubah dengan tambahan bunga atau mengandung unsur riba ${ }^{11}$.

Dalam kitabnya, Wahbah Az-Zuhaili menerangkan bahwa unsur terlaksananya gadai adalah sebagai berikut:

a. Ar-Rahin artinya yang menggadaikan;

b. Al-Murtahin artinya yang menerima gadai;

\footnotetext{
${ }^{10} \mathrm{http}$ ://armandrachmandd.blogspot.co.id/2015/06/hadits-gadai.html.

${ }^{11}$ Ahmad Sarwat, Fikih Sehari-hari (Jakarta: Gramedia Pustaka Utama, 2017), hal.93.
} 
c. Al-Marhun artinya barang yang digadaikan;

d. Al-Marhun bih artinya uang yang dipinjamkan lantaran ada barang yang digadaikan.

Namun menurut ulama Hanafiyah yang dikutip oleh Wahbah Az-Zuhaili, rukun gadai hanyalah ijab dan qabul dari Ar-Rahin dan Al-Murtahin.

Selain Hanafiyah berpendapat bahwa rukun gadai ada empat yaitu;shigat, yang berakad, barang yang digadaikan, dan uang yang dipinjamkan ${ }^{12}$.

\section{Syarat Penggadai dan Penerima Gadai}

Syarat-syarat orang yang akan menggadaikan adalah sebagai berikut keduaduanya harus mutlaq at-tasharruf artinya mereka adalah orang yang diberi kewenangan dalam mengolah harta ${ }^{13}$. Singkatnya, keduanya harus baligh, berakal, dan bukan mahjuur alaih (orang yang dilarang mengolah harta sendiri seperti orang yang memubadzirkan harta dan anak kecil).

\section{Ketentuan Barang yang Digadaikan}

Ketentuan barang yang digadaikan adalah sebagai berikut ${ }^{14}$ :

a. Setiap benda yang boleh dijualbelikan maka boleh pula untuk digadaikan. Sebaliknya, benda yang tidak boleh dijualbelikan maka tidak boleh digadaikan pula seperti, benda wakaf. Benda yang tidak dapat dijual tidak boleh digadaikan karena hal tersebut bertentangan dengan tujuan gadai yaitu menjamin utang yang tidak dapat dibayar dengan cara menjual barang gadai tersebut.

b. Yang digadaikan harus berupa benda. Maka tidak sah menggadaikan selain benda seperti menggadaikan utang. Karena ketentuan barang yang digadaikan adalah barang yang dapat diterima sedangkan utang adalah sesuatu yang tidak nampak sehingga tidak dapat diterima.

\section{Ketentuan Gadai}

a. Gadai tidak sah kecuali dengan ijab seperti:"aku menggadaikan” dan qabul seperti:"aku terima gadai".

b. Gadai diperuntukkan utang yang telah tetap. Maka, utang yang belum tetap tidak dapat diberi gadai seperti utang jual beli salm. Karena sebelum barang diterima salm bukanlah utang.

\footnotetext{
${ }^{12}$ Wahbah Az-Zuhaili, Al-Fiqh Al-Islam Wa Adillatuhu (Damsyiq: Dar Al-Fikr,1984), hal. 183

${ }^{13}$ Ahmad Al Raysuni and Muhammad Jamal Barut, "Ijtihad Antara Teks, Realitas, Dan Kemaslahatan Sosial," Jakarta: Penerbit Erlangga, 2002.

${ }^{14}$ Imam Taqiyuddin, Kifayatul Akhyar (Surabaya: Dar Al-Ilmi), hal. 214
} 
c. Penggadai dapat menarik kembali barang gadaiannya sebelum penggadai menyerahkan barang gadaiannya kepada penerima gadai.

d. Seorang penerima gadai tidak bertanggungjawab atas kerusakannya kecuali karena kelalaiannya. Hal ini dikaitkan pada kepercayaan, sama halnya seperti meminjam barang tidak ditanggung kerusakannya oleh peminjam kecuali karena kelalaiannya. Diantara bentuk kelalaian adalah menggunakan barang gadai tersebut bukan pada hak yang telah diberi izin oleh pemberi gadai.

e. Ketika peminjam uang membayar sebagian utangnya, maka barang gadaian tidak boleh diserahkan sampai utang tersebut dilunasi seluruhnya ${ }^{15}$.

\section{Ketentuan Gadai Menurut Hukum Perdata Indonesia}

Sebagaimana ketentuan dalam aturan peralihan pasal 1, bahwa setiap hukum peninggalan bangsa Belanda masih diberlakukan selama belum ada hukum penggantinya, maka dalam masalah hukum perdata bagi Warga Negara Indonesia diberlakukan Kitab Undang-Undang Hukum Perdata dan Burgerlijk Wetboek sudah tidak digunakan lagi.

Masalah gadai juga diatur dalam KUHPerdata Indonesia dalam pasal 1150 sampai 116o yang akan diuraikan sebagai berikut:

\section{Pasal 1150}

Gadai adalah suatu hak yang diperoleh kreditur atas suatu barang bergerak, yang diserahkan kepadanya oleh kreditur, atau oleh kuasanya, sebagai jaminan atas utangnya, dan yang memberi wewenang kepada kreditur untuk mengambil pelunasan piutangnya dan barang itu dengan mendahului kreditur-kreditur lain dengan pengecualian biaya penjualan sebagai pelaksanaan putusan atas tuntutan mengenai pemilikan atau penguasaan, dan biaya penyelamatan barang itu, yang dikeluarkan setelah barang itu sebagai gadai dan yang harus didahulukan.

\section{Pasal 1151}

Perjanjian gadai harus dibuktikan dengan alat yang diperkenankan untuk membuktikan perjanjian pokoknya.

\section{Pasal 1152}

Hak gadai atas barang bergerak yang berwujud dan atas piutang bawa timbul dengan cara menyerahkan gadai itu kepada kekuasaan kreditur atau orang yang memberikan gadai atau yang dikembalikan atas kehendak kreditur. Hak gadai hapus bila gadai itu lepas dari kekuasaan pemegang gadai. Namun bila barang itu hilang, atau diambil dari keuasaannya, maka ia berhak untuk menuntutnya kembali

\footnotetext{
${ }^{15}$ Imam Taqiyuddin, Kifayatul Akhyar (Surabaya: Dar Al-Ilmi), hal. 213
} 
menurut pasal 1977 alinea kedua, dan bila gadai itu telah kembali, maka hak gadai itu tidak pernah hilang.

Hal tidak adanya wewenang pemberi gadai untuk bertindak bebas atas barang itu, tidak dapat dipertanggungjawabkan kepada kreditur, tanpa mengurangi hak orang yang telah kehilangan atau kecurigaan barang itu untu menuntutnya kembali.

\section{Pasal 1152 bis}

Untuk melahirkan hak gadai atas surat tunjuk, selain penyerahan endosemennya, juga dipersyaratkan penyerahan suratnya.

\section{Pasal 1153}

Hak gadai atas barang yang tak berwujud, kecuali surat tunjuk dan surat bawa lahir dengan pemberitahuan mengenai penggadaian itu kepada orang yang kepadanya hak gadai itu harus dilaksanakan. Orang ini dapat menuntut bukti tertulis mengenai pemberitahuan itu, dan mengenai izin dan pemberian gadainya.

\section{Pasal 1154}

Dalam hal debitur atau pemberi gadai tidak memenuhi kewajiban-kewajiban, kreditur tidak diperkenankan mengalihkan barang yang digadaikan itu menjadi miliknya. Segala persyaratan perjanjian yang bertentangan dengan ketentuan ini adalh batal.

\section{Pasal 1155}

Bila oleh pihak-pihak berjanji tidak disepakati lain, maka jika debitur atau pemberi gadai tidak memenuhi kewajibannya setelah lampaunya jangka waktu yang ditentukanatau setelah dilakukan peringatan untuk pemenuhan perjanjian dalam hal tidak ada ketentuan tentang jangka waktu yang pasti kreditur berhak untuk menjual barang gadainya di hadapan umum menurut kebiasaan-kebiasaan setempat dan dengan persyaratan yang lazim berlaku, dengan tujuan agar jumlah utang itu dengan bunga dan biaya dapat dilunasi dengan hasil penjualan itu. Bila gadai itu terdiri dari barang dagangan atau dan efek-efek yang dapat diperdagangkan dalam bursa, maka penjualannya dapat dilakukan di tempat itu juga, asalkan dengan perantaraan dua orang makelar yang ahli di bidang itu.

\section{Pasal 1156}

Dalam segala hal bila debitur atau pemberi gadai lalai dalam melakukan kewajibannya, maka debitur dapat menuntut lewat pengadilan agara barang gadai dijual untuk melunasi utangnya beserta bunga dan biayanya menurut cara yang akan ditentukan oleh hakim atau agar hakim mengizinkan barang gadai itu tetap berada pada kreditur untuk menutup suatu jumlah yang akan ditentukan oleh hakim dalam suatu keputusan sampai sebesar utang beserta bunga dan biayanya.

Tentang pemindahtanganan barang gadai yang dimaksud dalam pasal ini dan pasal yang lampau kreditur wajib memberitahukannya kepada pemberi gadai selambat-lambatnya pada hari berikutnya bila setiap hari ada hubungan pos atau 
telegrap atau jika tidak begitu halnya dengan pos yang berangkat pertama. Berita dengan telegrap atau dengan surat tercatat dianggap sebagai berita yang pantas.

\section{Pasal 1157}

Kreditur bertanggungjawab atas kerugian atau susutnya barang gadai itu, sejauh hal itu terjadi akibat kelalaiannya. Di pihak lain debitur wajib mengganti kepada kreditur itu biaya yang berguna dan perlu dikeluarkan oleh kreditur itu untuk penyelamatan barang gadai itu.

\section{Pasal 1158}

Bila suatu piutang digadaikan dan piutang ini menghasilkan bunga maka kreditur boleh memperhitungkan bunga itu dengan bunga yang teritung kepadanya.

Bila utang yang dijamin dengan piutang yang digadaikan itu tidak menghasilkan bunga maka bunga dapat diterima pemegang gadai itu dikurangkan dari jumlah pokok utang.

\section{Pasal 1159}

Selama pemegang gadai itu tidak menyalahgunakan barang yang diberikan kepadanya sebagai gadai debitur tidak berwenang untuk menuntut kembali barang itu sebelum ia membayar penuh baik jumlah uanag pokok maupun bunga dan biaya piutang yang dijamin dengan gadai itu beserta biaya yang dikeluarkan untuk penyelamatan barang gadai itu.

Bila antara kreditur dan debitur terjadi utang kedua yang diadakan antara mereka berdua setelah saat pemberian gadai dan dapat ditagih sebelum pembayaran utang yang pertama atau pada hari pembayaran itu sendiri maka kreditur tidak wajib melepaskan barang gadai itu sebelum ia menerima pembayaran penuh kedua utang itu walaupun tidak diadakan perjanjian untuk mengikatkan barang gadai itu bagi pembayaran utang yang kedua.

\section{Pasal 116o}

Gadai itu tidak dapat dibagi-bagi,meskipun utang itu dapat dibagi antara para ahli waris debitur atau para ahli waris kreditur.ahli waris debitur yang telah membayar bagiannya tidak dapat menuntut kembali bagiannya dalam barang gadai itu,sebelum utang itu dilunasi sepenuhnya.di lain pihak,ahli waris kreditur yang telah menerima bagiannya dan piutang itu,tidak boleh mengembalikan barang gadai itu atas kerugian sesama ahli warisnya yang belum menerima pembayaran.

Dalam ketentuan hukum perdata, istilah gadai hanya diperuntukkan untuk barang bergerak. Adapun jaminan yang berbentuk barang tidak bergerak, dalam hukum perdata disebut dengan istilah hipotek dan berikut penjelasan hukumnya.

\section{Pasal 1162}

Hipotek adalah suatu hak kebendaan atas barang tak bergerak yang dijadikan jaminan dalam pelunasan suatu perikatan. 


\section{Pasal 1163}

Hak itu pada hakikatnya tidak dapat dibagi-bagi, dan diadakan atas semua barang tak bergerak yang terikat secara keseluruhan, atau masing-masing dari barangbarang itu, dan atas tiap bagian dari brang-barang itu. Barang-barang tersebut tetap memikul beban itu meskipun barang-barang tersebut berpindah tangan kepada siapapun juga.

\section{Pasal 1164}

Yang dapat dibebani dengan hipotek hanyalah:

1. Barang-barang tak bergerak yang dapat diperdagangkan, beserta semua yang termasuk bagiannya, sejauh hal yang tersebt terakhir ini dianggap sebagai barang tak bergerak;

2. Hak pakai hasil barang-barang itu dengan segala sesuatu yang termasuk bagiannya;

3. Hak numpang karang dan usaha;

4. Bunga tanah yang terutang baik dalam bentuk uang maupun dalam bentuk hasil tanah;

5. Hak sepersepuluhan;

6. Bazar atau pekan raya yang diakui oleh pemerintah beserta hak istimewanya melekat.

Berdasarkan pasal-pasal tersebut di atas, maka ketentuan gadai adalah sebagai berikut:

1. Adanya utang yang tetap bagi penggadai;

2. Barang yang digadaikan adalah benda bergerak;

3. Perjanjian gadai harus dibuktikan dalam sebuah perikatan

4. Apabila benda yang digadaikan itu hilang atau dicabut dari kepemilikan penggadai maka kreditur (istilah bagi orang yang memiliki hak) boleh menuntut. Namun saat barang kembali, maka hak gadai tidak hilang.

5. Ketika debitur (istilah bagi orang yang menggadaikan barangnya) tidak bisa melunasi kewajibannya, maka kreditur tidak dapat langsung memindahtangankan kepemilikan kepadanya, namun kreditur berhak menjual barang itu dengan mengambil hasil penjualan yang dapat melunasi utang serta biaya selama barang gadai itu digadaikan.

6. Bila kreditur lalai dalam menjaga barang gadi sehingga terjadi kerusakan, maka kreditur bertangggung jawab atas kelalaiannya.

Dalam lingkungan pegadaian, Lembaga Pegadaian di Indonesia sudah dimulai ketika Indonesia belum merdeka. Pada awalnya lembaga ini adalah merupakan 
lembaga swasta, keadaan ini juga berkelanjutan pada masa-masa awal kemerdekaan dan barulah pada tahun 1961 lembaga ini berubah menjadi Perusahaan Negara, dan selanjutnya berdasarkan Keputusan Presiden Nomor 18o tahun 1965 Perusahaan Negara Pegadaian diintegrasikan ke dalam urusan Bank Sentral, dan selanjutnya berdasarkan Peraturan Pemerintah Nomor 7 tahun 1969 Perusahaan Negara Pegadaian diubah statusnya menjadi Perusahaan Jawatan Pegadaian.

Menurut aturan dasar pegadaian, barang-barang yang dapat digadaikan di lembaga ini hanyalah berupa barang-barang bergerak (gadai dalam KUHPerdata hanyalah berbentuk barang-barang bergerak), tentunya dengan beberapa pengecualian.

Adapun barang-barang yang dikecualikan tersebut yang tidak dapat digadaikan adalah:

1. Barang milik negara, seperti sepeda motor dinas, mesin tik kantor.

2. Surat utang, surat actie, surat efek dan surat-surat berharga lainnya.

3. Hewan yang hidup dan tanaman.

4. Segala makanan dan benda yang mudah busuk.

5. Benda-benda yang kotor.

6. Benda-benda yang untuk menguasai dan memindahkannya dari satu tempat ke tempat lain memerlukan izin.

7. Barang yang karena ukurannya yang besar tidak dapat disimpan dalam gadaian.

8. Barang yang berbau busuk dan mudah merusak barang lain jika disimpan bersama-sama.

9. Benda yang hanya berharga sementara atau yang harganya naik turun dengan cepat sehingga sulit ditaksir oleh pejabat gadai.

10. Benda yang digadaikan oleh seseorang yang mabuk atau tidak dapat memberikan keterangan-keterangan tentang barang yang digadaikannya.

Dalam praktik, barang-barang yang lazim diterima oleh Jawatan Pegadaian adalah barang-barang seperti:emas, permata, jam, sepeda, kain sutra, atau barangbarang lainnya yang berharga.

Peminjaman uang pada jawatan pegadaian ini dikenakan bunga, menyangkut besarnya suku bunga selalu mengalami perubahan dan disesuaikan dengan kondisi perekonomian.

Dibandingkan dengan peminjaman uang ke Bank, khususnya pinjaman kecil, suku bunga pada jawatan pegadaian ini relatif lebih besar. Sebab perhitungan bunga pada jawatan pegadaian dihitung per 15 hari, dengan demikian apabila pembayaran dilakukan pada hari ke 16 maka bunga yang harus dibayar sudah dua kali lipat, demikian seterusnya setiap 15 hari. 
Ketentuan gadai dalam hukum perdata, jika disimpulkan adalah sebagai berikut:

1. Pengertian gadai adalah hak yang diperoleh kreditur atas benda bergerak yang diserahkan padanya oleh debitur yang memeberikan kekuasaan pada kreditur untuk mengambil pelunasan dari barang dengan hak preferent.

2. Objek gadai adalah semua barang bergerak.

3. Para pihak dalam gadai adalah debitur (pemberi gadai), kreditur (penerima gadai).

4. Sifat dan tujuan gadai adalah; hak preferent, bersifat kebendaan, sebagai perjanjian ikutan, menjadi pelunasan hutang, tidak dapat dibagi-bagi dan inbezitstelling (penyerahan)

5. Syarat sahnya gadai harus ada penyerahan atas benda yang dijadikan jaminan (inbezitstelling) dan benda yang digadaikan harus dikeluarkan dari kekuasaan pemberi gadai.

\section{Hukum Pemanfaatan Barang Gadai Menurut Hukum Islam}

Terdapat perbedaan pendapat para ulama tentang siapa yang berhak atas manfaat yang dihasilkan dari barang yang digadaikan; apakah menjadi hak pemberi gadai atau penerima gadai. Perbedaan pendapat tersebut diuraikan sebagai berikut:

\section{Madzhab Maliki}

Hasil dari barang gadai adalah hak bagi penggadai, selama penerima gadai tidak mensyaratkan hal itu. Maka apabila penerima gadai mensyaratkan hal itu, buah atau hasil barang gadai adalah milik penerima gadai dengan memiliki tiga syarat:

a. Utang disebabkan oleh jual beli bukan sebab utang piutang.

Contoh: Si A menjual tanah kepada $\mathrm{Si}$ B dengan harga yang ditangguhkan. Kemudian Si B menggadaikan sebuah barang milik B kepada Si A sebagai perbandingan utangnya.

b. Penerima gadai mensyaratkan bahwa manfaat barang gadai untuk dirinya. Apabila penerima gadai dengan keikhlasannya memberikan manfaat kepada pemberi gadai, maka penerima gadai tidak boleh mengambil manfaat dari barang gadai tersebut.

c. Waktu pemanfaatan ditentukan oleh batas.

Tidak diharuskan manfaat dari barang gadai diperuntukkan pemberi gadai dengan mengelola barang gadai tersebut. Atau tidak seharusnya barang gadai ada di bawah tangan pemberi gadai secara keseluruhan. Karena sebenarnya gadai berada di bawah tangan penerima gadai tetapi manfaatnya untuk pemberi gadai jika syarat tersebut tadi diatas tidak terpenuhi. 
Apabila seseorang menggadaikan sebuah rumah kemudian penerima gadai menyewakan rumah tersebut maka hasil dari sewa rumah diserahkan kepada pemberi gadai. Namun apabila penerima gadai mengizinkan pemberi gadai untuk menyewakan rumah tersebut atau apabila penerima gadai memberi izin pemberi gadai untuk menempati rumah tersebut, maka akad gadai batal.

\section{Madzhab Syafi'i}

Ulama Syafi'iyah mengatakan bahwa orang yang menggadaikan adalah orang yang berhak atas manfaat barang yang digadaikan karena barang yang digadaikan adalah barang di bawah tangan penerima gadai. Karena di bawah tangan maka penerima gadai tidak boleh mengangkatkan tangannya atas manfaat barang gadaian. Oleh karena itu barang gadaian dikembalikan kepada penggadai saat diambil manfaatnya. Kemudian apabila penerima gadai tidak mampu mengembalikan barang gadaian untuk diambil manfaatnya maka penerima gadai harus bersaksi atas hal itu.

Penggadai juga boleh memanfaatkan hal yang tidak akan mengurangi dzat barang gadaian seperti menempati rumahnya atau menaiki kendaraannya tanpa harus ada izin dari penerima gadai. Hal ini berdasarkan hadits Rasulullah SAW.

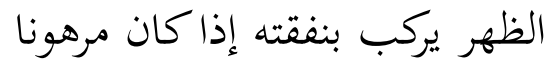

Artinya: "punggung itu ditunggangi serta nafkahnya jika digadaikan".

Seorang yang menggadaikan tidak boleh mendirikan bangunan di atas tanah yang digadaikan atau menanam tanaman di atasnya. Apabila hal tersebut dilakukan, tidak mesti bangunan tersebut dihancurkan atau tanaman tersebut di tebang sebelum pelunasan utang. Adapun ketika utang telah beres atau jatuh tempo kemudian bangunan atau tanaman mempengaruhi terhadap harga tanah sehingga utang tidak dapat terpenuhi maka bangunan atau tanaman tersebut mesti di hilangkan. Namun apabila tidak mempengaruhi maka tidak perlu dihilangkan. Bangunan dan tanaman tidak termasuk barang gadai karena hal itu terjadi setelah akad. Adapun penggunaan yang menyebabkan berkurangnya harga barang gadai, maka hal tersebut tidak diperbolehkan kecuali dengan izin penerima gadai.

Tidak sah hukumnya jika penggadai menyewakan barang gadaian setelah serah terima barang gadai yang mana waktu sewaan melebihi batas waktu gadai. Adapun jika waktu sewaan sudah beres pada saat tempo utang atau sebelum jatuh tempo utang maka sewaan tersebut sah karena tidak merugikan penerima gadai, atau penerima gadai mengizinkan hal tersebut. Dan dibolehkan izin tersebut ditarik kembali sebelum penggadai melakukan sewa tersebut. Apabila penerima gadai mensyaratkan pada saat akad bahwa manfaat barang gadai adalah untuk dirinya maka akad itu merugikan penggadai. Tidak sah seorang 
penerima gadai memanfaatkan barang gadai ketika menentukan saat akad. Namun apabila penggadai mengizinkan pemanfaatana tersebut maka hukumnya boleh.

\section{Madzhab Hanafi}

Seorang penggadai tidak diperbolehkan memanfaatkan barang gadai kecuali seizin penerima gadai. Maka seseorang tidak boleh menempati rumah yang digadaikan, mengendarai kendaraan yang digadaikan dan lain sebagainya kecuali seizin penerima gadai selama barang itu masih dalam masa pegadaian, baik penggunaan itu menyebabkan berkurangnya harga barang atau tidak. Namun apabila penerima gadai mengizinkan maka hal itu diperbolehkan.

Sebenarnya manfaat barang gadai dan apa saja yang dihasilkan dari barang gadai adalah hak seorang penggadai baik itu anak dari hewan yang digadaikan, susunya, telurnya, buahnya atau yang lainnya. Jika barang gadai rusak sebelum utang dilunasi maka barang gadai tidak dianggap ada. Artinya barang gadai harus diganti dengan yang lain.

Adapun pemanfaatan barang gadai oleh penerima gadai terdapat perbedaan pendapat. Sebagian ulama berpendapat bahwa tidak boleh bagi seorang penerima gadai memanfaatkan barang gadai baik itu menjual, menyewakan dan sebagainya. Karena seorang penggadai akan melunasi utangnya secara keseluruhan. Dengan begitu bagi seorang penerima gadai mendapatkan manfaat tanpa ada bandingan keuntungan bagi penggadai, dan ini termasuk riba. Namun kebanyakan ulama berpendapat bahwa penerima gadai boleh memanfaatkan barang gadai apabila penggadai mengijinkan dengan syarat tidak ada ketentuan ketika akad, karena jika disyaratkan saat akad maka hal tersebut termasuk riba.

\section{Madzhab Hambali}

Barang yang digadaikan, baik itu hewan yang ditunggangi atau diperas susunya atau baik barang itu bukan hewan, maka penerima gadai boleh memanfaatkan barang gadai itu tanpa seizin penggadai. Adapun jika barang yang digadaikan bukan hewan yang ditunggangi atau yang diperas susunya, maka penerima gadai boleh memanfaatkan barang itu dengan seizin penggadai.

Dalam referensi lain dikatakan bahwa pemanfaatan barang gadai menurut ketentuan hukum Islam tetap merupakan hak si penggadai, termasuk hasil barang gadaian tersebut seperti anaknya, buahnya dan bulunya. Sebab perjanjian dilaksanakan hanyalah untuk menjamin utang, bukan untuk mengambil suatu keuntungan, dan perbuatan pemegang gadai memanfaatkan barang gadaian adalah merupakan perbuatan qiradl (ialah harta yang diberikan kepada seseorang kemudian ia mengembalikannya setelah mampu) yang 
melahirkan kemanfaatan dan setiap jenis qiradl yang melahirkan kemanfaatan dipandang sebagai riba.

Namun demikian apabila jenis barang gadaian tersebut berbentuk binatang yang bisa ditunggangi atau diperah susunya, maka si penerima gadai dibolehkan untuk menggunakan atau memerah susunya. Hal ini dimaksudkan sebagai imbalan jerih payah si penerima gadai memelihara dan memberi makan binatang gadaian tersebut. Sebab orang yang menunggangi atau memerah susu binatang mempunyai kewajiban untuk memberi makan binatang tersebut.

Dasar hukum pembolehan ini dapat diperhatikan dalam ketentuan sunnah Rasulullah SAW.yang diriwayatkan oleh Jama'ah kecuali Muslim dan Nasai yang artinya sebagai berikut:

Dari Abu Hurairah, dari Nabi SAW., beliau bersabda: "Boleh menunggangi binatang gadaian yang ia beri makan. Begitu juga boleh mengambil susu binatang gadaian jika ia memberi makan. Kewajiban yang menunggangi dan mengambil susu memberi makan"16.

Dari uraian di atas dapat disimpulkan, bahwa dalam tinjauan hukum Islam, para ulama madzhab berbeda pendapat tentang boleh atau tidaknya mengambil manfaat dari barang yang digadaikan. Akan tetapi, meskipun berbeda pendapat, pada dasarnya pendapat-pendapat itu mempunyai pandangan yang sama akan bolehnya mengambil manfaat barang yang digadaikan oleh penerima gadai, atas izin pemberi gadai. Dengan demikian, inti permasalahan dalam pemanfaatan barang gadai adalah adanya saling ridha antara pemberi gadai dan penerima gadai.

\section{Hukum Pemanfaatan Barang Gadai Menurut Hukum Perdata Indonesia.}

Setelah diuraikan pasal-pasal dalam KUHPerdata tentang ketentuan gadai, maka dapat disimpulkan bahwa gadai adalah perikatan dengan ketentuan hanya sebagai jaminan, bukan pemindahan hak pakai atau hak guna (pasal 1150). Bahkan apabila dalam pemanfaatan barang tersebut dapat mengurangi atau merusak barang gadai tidak menjadikan utang penggadai lunas, namun penerima gadai wajib mengganti kerugian tersebut.

Dalam praktek lembaga pegadaian di Indonesia yang sesuai dengan KUHPerdata, barang yang dapat digadaikan adalah barang yang dapat disimpan di pegadaian. Itu artinya barang gadai disimpan sebagai jaminan bukan untuk digunakan.

Dalam pasal 1152 disebutkan bahwa “. hal tidak adanya wewenang pemberi gadai untuk bertindak bebas atsa barang itu....... Berarti pemberi gadai juga tidak bebas memanfaatkan atau mengolah barang gadai tersebut. Bahkan ketika barang

${ }^{16}$ Chaeruman Pasaribu dan Suhrawardi, Hukum Perjanjian Dalam Islam (Jakarta:Sinar Grafika Offset, 1996, hal. 143. 
gadai hilang atau rusak di tangan pemberi gadai, selama utang penggadai belum lunas maka barang gadai harus diganti.

Karena dalam hukum perdata di Indonesia istilah gadai hanya diperuntukkan benda bergerak, maka pemanfaatan barang gadai tidak diperbolehkan baik oleh pemberi gadai ataupun penerima gadai. Hal ini dikaitkan dengan pengertian gadai yang diperuntukkan sebagai jaminan.

\section{Perbandingan Hukum Gadai Menurut Hukum Islam dan Hukum Perdata di Indonesia.}

Dari beberapa penjelasan di atas tentang gadai menurut hukum Islam dan Hukum Perdata Indonesia terdapat perbedaan yang sangat signifikan terutama dalam masalah benda yang dapat digadaikan. Untuk itu perbedaan dan persamaan tersebut dapat dirinci sebagai berikut:

1. Persamaan Hukum.

a. Gadai menurut keduanya adalah sebuah barang jaminan atas utang yang telah ditetapkan.

b. Jika penggadai tidak dapat melunasi utangnya, maka penerima gadai dapat mengambil pelunasan utangnya itu dengan menjual barang yang digadaikan.

c. Harus ada penyerahan barang gadai atau dalam hukum Islam disebut dengan akad dan dalam hukum perdata disebut inbezitstelling.

2. Perbedaan Hukum.

a. Dalam hukum Islam barang yang dapat digadaikan adalah semua barang yang dapat diperjualbelikan sedangkan dalam hukum perdata barang yang digadaikan hanya barang bergerak saja. Adapun istilah untuk barang tidak bergerak yang dijadikan jaminan adalah hipotek.

b. Dalam masalah pemanfaatan barang yang digadaikan, menurut hukum Islam ada beberapa pendapat madzhab diantaranya:

1) Menurut madzhab Hanafi, Syafi'i dan Maliki barang yang digadaikan tetap berada dibawah kekuasaan penggadai dan manfaat atau hasil dari barang gadai seperti anak, buah dan sebagainya itu hak penggadai. Namun penggunaan yang dapat mengakibatkan berkurangnya harga barang gadai harus seizin penerima gadai.

2) Menurut madzhab Hambali pemberi gadai boleh memanfaatkan barang gadai tanpa sizin penerima gadai.

Jadi, dalam hukum Islam kekuasaan atas benda gadai itu tidak terlepas dari kekuasaan penggadai. Hanya akad perjanjian yang mengikat barang gadai itu bukan atas kepemilikan barang. 
Sedangkan dalam hukum perdata, baik penggadai ataupun penerima gadai keduanya tidak berhak atas pemanfaatan barang gadai tersebut.

c. Antara jaminan barang bergerak dan tidak bergerak dalam hukum Islam memiliki istialh yang sama yaitu gadai atau rahn. Sedangkan dalam hukum perdata istilah gadai hanya diperuntukkan bagi barang bergerak dan hipotek untuk barang tidak bergerak.

d. Benda bergerak yang digadaikan dalam lingkungan pegadaian di Indonesia sangat terbatas yaitu hanya meliputi barang seperti emas, permata, jam, kain sutra dan barang berharga lainnya.

\section{Simpulan}

Dari paparan di atas tentang pemanfaatan barang gadai menurut hukum Islam dan hukum perdata di Indonesia dapat disimpulkan bahwa:

1. Gadai menurut hukum Islam adalah menjadikan harta benda yang boleh dijual sebagai jaminan atas utang yang akan memenuhi atau melunasi utang tersebut ketika peminjam tidak mampu untuk melunasi.

2. Gadai menurut hukum perdata Indonesia adalah suatu hak yang diperoleh kreditur atas suatu barang bergerak, yang diserahkan kepadanya oleh kreditur, atau oleh kuasanya, sebagai jaminan atas utangnya, dan yang memberi wewenang kepada kreditur untuk mengambil pelunasan piutangnya dan barang itu dengan mendahului kreditur-kreditur lain dengan pengecualian biaya penjualan sebagai pelaksanaan putusan atas tuntutan mengenai pemilikan atau penguasaan, dan biaya penyelamatan barang itu, yang dikeluarkan setelah barang itu sebagai gadai dan yang harus didahulukan.

3. Dalam hal pemanfaatan barang gadai, hukum Islam memiliki beberapa pendapat madzhab yang berbeda yang semuanya dapat diikuti dengan dalil masing-masing madzhab. Namun menurut hukum perdata barang gadai itu untuk disimpan dan tidak untuk dipergunakan. Oleh karena itu barang yang digadaikan tidak boleh barang yang cepat rusak. 


\section{DAFTAR PUSTAKA}

Az-Zuhaili, Wahbah. “Al-Fiqh Al-Islam Wa Adillatuhu, Cet. Ke-3.” Damaskus: Dar Al-Fikr, 1989.

Bajuri, Syeikh Ibrahim Al. “Hasyiah Al Bajuri „ala Ibnu Qosim Al Ghuzzi.” Jakarta: PT Karya Insani, n.d.

Muin, Abd, and Ahmad Khotibul Umam. "EKSISTENSI KOMPILASI HUKUM ISLAM DALAM SISTEM HUKUM POSITIF.” Risâlah, Jurnal Pendidikan Dan Studi Islam 3, no. 1 (2016): 63-77.

Pasaribu, Chairuman, and Suhrawardi K Lubis. Hukum Perjanjian Dalam Islam. Penerbit Sinar Grafika, 1994.

Raysuni, Ahmad Al, and Muhammad Jamal Barut. "Ijtihad Antara Teks, Realitas, Dan Kemaslahatan Sosial.” Jakarta: Penerbit Erlangga, 2002.

Sumadi, Sumadi. "IDEOLOGI BIAS GENDER DALAM LEMBARAN FIKIH POPULER DI INDONESIA." Al-Afkar, Journal For Islamic Studies 1, no. 1 (2018): 1-15.

Taqiyuddin, Imam. "Kifayat Al-Akhyar Fi Hal Ghayat Al-Ikhtiyar." Bandung: AlMaarif, TT, n.d.

Wibowo, Sunarto Ady. "Perwalian Menurut KUHP Perdata Dan UU No. 1 Tahun $1974, " 2004$.

Abdurrahman al-Jazairi, Kitab Al-Fiqh 'ala Al-Madzahib Al-Arba'ah (Kairo: Dar AlHadits, Tanpa Tahun).

Ahmad Sarwat, Fikih Sehari-hari (Jakarta: Gramedia Pustaka Utama, 2017).

Beni Ahmad Saebani, Ilmu Ushul Fiqh (Bandung: Pustaka Setia, 2009). 